\title{
Cerebral Venous Sinus Thrombosis with Internal Jugular Venous Thrombosis in a Male Patient with Nephrotic Syndrome
}

\section{Nefrotik Sendromlu Erkek Hastada Serebral Venöz Sinüs Trombozu ile Birlikte Internal Jugular Ven Trombozu}

\section{Cigdem HACIFAZLIOGLU ${ }^{1}$, Erhan ARSLAN ${ }^{2}$, Elif ACAR ARSLAN ${ }^{3}$, Gulseren BUYUKSERBETCI ${ }^{4}$}

${ }^{1}$ Kecioren Training and Research Hospital, Department of Radiology, Ankara, Turkey

${ }^{2}$ Giresun University School of Medicine, Department of Neurosurgery, Giresun, Turkey

${ }^{3}$ Hacettepe University, School of Medicine, Department of Pediatric Neurology, Ankara, Turkey

${ }^{4}$ Kecioren Training and Research Hospital, Department of Neurology, Ankara, Turkey

Presented in: This case was presented as a poster in the $27^{\text {th }}$ Turkish Neurosurgical Society Scientific Congress 12-16 April, 2013, Antalya, Turkey.

Corresponding Author: Erhan ARSLAN / E-mail: arserhan@gmail.com

\begin{abstract}
Cerebral venous sinus thrombosis with internal jugular vein thrombosis is not reported as a complication in nephrotic syndrome. We report a 40-year-old male with nephrotic syndrome, who had headache during his hospitalization. Conventional diagnostic tests showed extensive thrombosis at the proximal part of superior sagittal sinus, left cortical vein, left sigmoid-transverse sinus and left internal jugular vein. The patient underwent medical treatment and was discharged in good health after 2 weeks. The aim of this study is to report a novel case of cerebral venous sinus thrombosis with internal jugular venous thrombosis in a male patient with nephrotic syndrome.
\end{abstract}

KEYWORDS: Cerebral venous system thrombosis, MR venography, Nephrotic syndrome

Öz

İnternal jugular ven trombozu ile birlikte serebral venöz sinüs trombozu, nefrotik sendromun bir komplikasyonu olarak bildirilmemiştir. Hastanede yattığı sürede başağrısı şikayeti olan 40 yaşında nefrotik sendromlu bir erkek hastayı bildirmekteyiz. Konvansiyonel görüntüleme yöntemleri ile süperior sagittal sinüs proksimal kısmında, sol kortikal vende, sol sigmoid-transvers sinüsde ve sol internal jugular vende belirgin tromboz tespit edildi. Hastaya medikal tedavi uygulandı ve 2 hafta sonra sağlıklı olarak taburcu edildi. Bu çalışmanın amacı, serebral venöz sinüs trombozu ile birlikte internal jugular ven trombozu olan nefrotik sendromlu yeni bir olguyu sunmaktır.

ANAHTAR SÖZCÜKLER: Serebral venöz sistem trombozu, MR venografi, Nefrotik sendrom

\section{INTRODUCTION}

Cerebral venous sinus thrombosis (CVST) seems to have become more common in the recent years, due to improved diagnosis with the use of modern imaging techniques. Clinically, diagnosis can be very difficult but earlier diagnosis and treatment may be achieved by using modern imaging modalities. CVST is a commonly occurring complication in nephrotic syndrome patients $(4,16)$ and can be cured with early diagnosis and treatment (7). This entity can also result in severe mortality and morbidity if the diagnosis and treatment initiation are late. 12 adult cases with cerebral venous sinus thrombosis in nephrotic syndrome were reported in the literature (1-3, 5-16). In this case, we are presenting an adult nephrotic syndrome patient with internal jugular venous thrombosis, in addition to intracranial segmental cerebral venous sinus thrombosis. We present a patient with a novel location-type of venous thrombosis in nephrotic syndrome.
To the best of our knowledge, this is the first case ever reported in the literature with this type.

\section{CASE REPORT}

A 40-year-old male was referred to our hospital with headache. His mental status did not change during his hospitalization. He was previously diagnosed with nephrotic syndrome at another clinic. Therefore, we suspected cerebral thrombosis, infarction and hemorrhage. On biochemical analysis, total serum protein, serum albumin, serum creatinine, blood urea, total cholesterol, serum fibrinogen and platelet count values were $3.78 \mathrm{~g} / \mathrm{dl}, 1.39 \mathrm{~g} / \mathrm{dl}, 0.89 \mathrm{mg} / \mathrm{dl}, 31.3 \mathrm{mg} / \mathrm{dl}, 264 \mathrm{mg} /$ $\mathrm{dl}, 157 \mathrm{mg} / \mathrm{dl}, 208 \times 10^{3} / \mu \mathrm{L}$ respectively. Serum d-dimer was positive and urine sedimentation was normal. Hemorrhagic infarction was detected at the left frontoparietal region on non-contrast computed brain tomography (BT) (Figure 1A). We suspected left cortical venous and superior sagittal sinus 


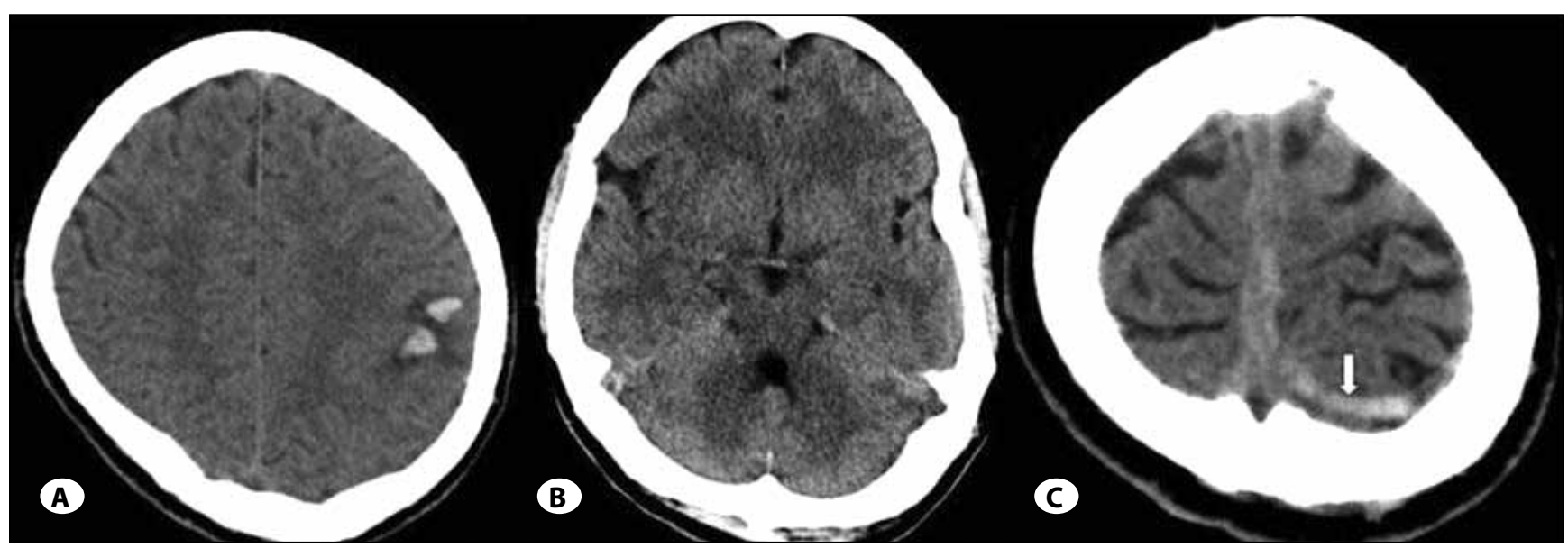

Figure 1: Computed Brain Tomography (BT) without contrast, showing A) A hemorrhage in the left parietal lobe associated with cerebral edema; B) No hemorrhage at the section passing from the cerebellum; C) Cerebral venous thrombosis in the left cortical vein (arrow).

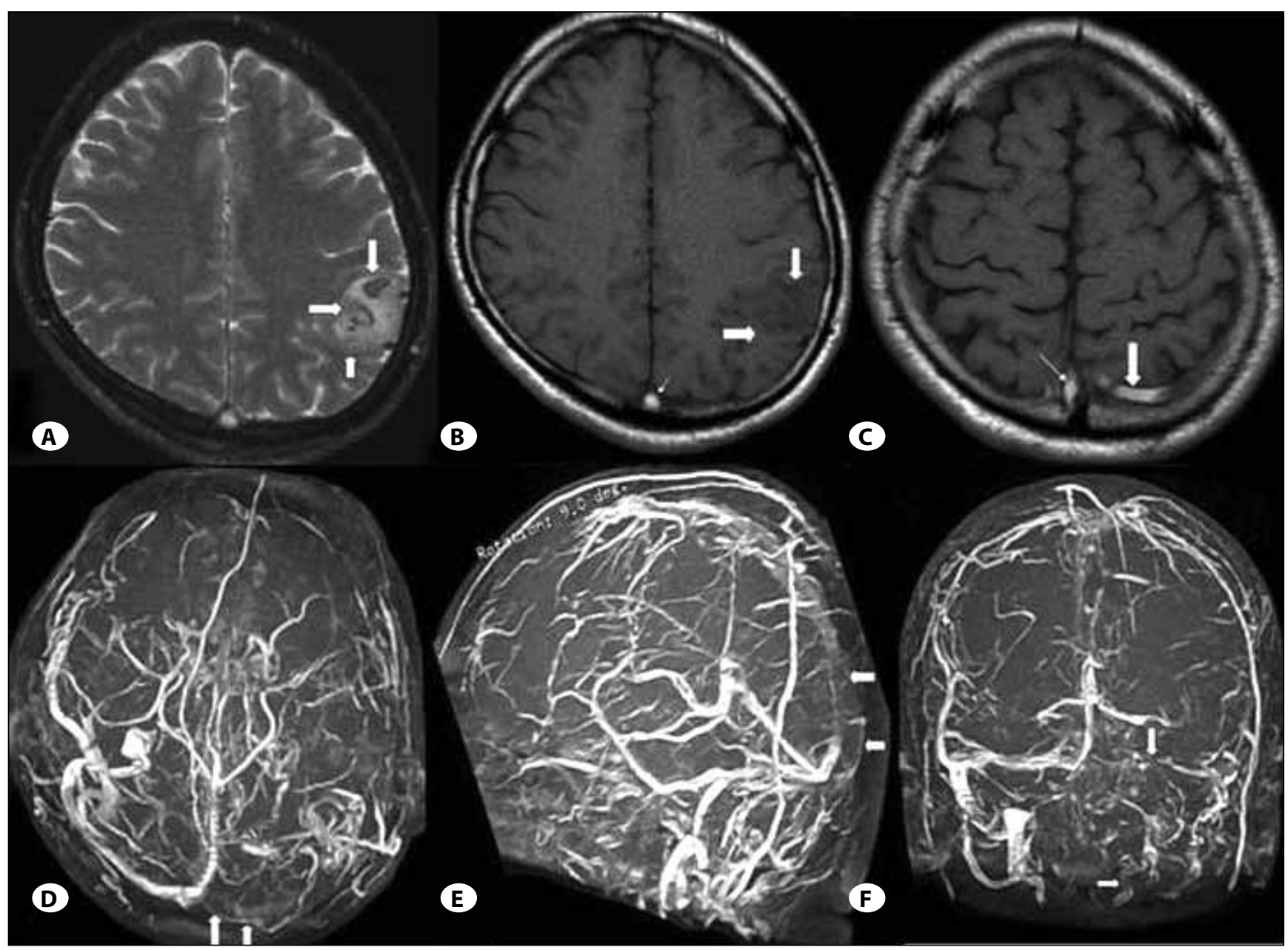

Figure 2: Magnetic Resonance Imaging of the patient. A) T2W MRI without contrast and B) T1W MRI without contrast, showing hemorrhage in the left parietal lobe with surrounding cerebral edema (arrows); C) T1W MRI without contrast showing hyperintensity in the left cortical vein (thick arrow) and superior sagittal vein (thin arrow) indicating cerebral venous thrombosis. Magnetic Resonance Venography of the patient: D) Cerebral Sinus Venous Thrombosis (CSVT) in the confluens sinuum and the left transverse sinus (arrows); E) CSVT in the superior sagittal sinus; F) CSVT in the left transverse and sigmoid sinuses and in the left internal jugular vein (arrows) are shown. 
thrombosis on non-contrast BT (Figure $1 \mathrm{~B}-\mathrm{C}$ ), and cranial magnetic resonance imaging (MRI) and MR venography were therefore performed. Cranial MRI showed an area of hemorrhagic infarction and edema at the left frontoparietal region and thrombosis at the superior sagittal sinus and left cortical vein (Figure 2A-C). Thrombosis at the proximal part of superior sagittal sinus, left cortical vein, left sigmoidtransverse sinus and left internal jugular vein were detected on MR venography (Figure 2D-F).

The patient was hospitalized and medical treatment was started. The hemorrhage was resorbed in two weeks. Epilepsy occurred during the follow-up of the patient and antiepileptic treatment was started. The patient got better gradually and was discharged from the hospital with oral anticoagulation treatment.

\section{DISCUSSION}

The correlation between nephrotic syndrome and thromboembolism is well-known $(4,9)$. Thrombosis can occur in both the arterial and venous system $(4,13,16)$. Several hematological changes can result in nephrotic syndrome, such as loss of anticoagulant factors (plasminogen, antithrombin 3, protein $\mathrm{C}$ and $\mathrm{S})$, increase in the production of coagulation factors (factor 5, combine factor 7, 10 and fibrinogen), hypercholesterolemia, thrombocytosis and platelet hyperactivity $(4,11$, 16). Arterial thrombosis is more common in pediatric cases, while venous thrombosis is more common in adult cases (4). The location of venous thrombosis is mostly the renal vein and the incidence rate is $10-20 \%$. The incidence at other locations is $20 \%$ and pulmonary embolism is the most common manifestation $(9,11)$. In our case, which was under steroid treatment, there was ipsilateral internal jugular vein thrombosis concomitant with multiple segmental cerebral sinovenous involvement, and anticoagulation treatment was started according to these findings. Otherwise, the diagnosis of central venous sinus thrombosis can be made with the existing neurological symptoms in patients with nephrotic syndrome. The diagnosis can easily be made by using BT and MR imaging and obtaining a proper clinical history. BT is the first imaging modality and thrombosis is manifested as hyperdensity on non-contrast BT $(5,8,11,14)$. In the first BT of our case, there were dilated hyperdense images at the left cortical vein at the vertex level, and there also were hyperdense hemorrhagic areas, which have peripheral hypodense edematous areas in the left parietal lobe. On the other hand, BT with contrast is a better modality for identifying dural venous sinus thrombosis, and the vascular endoluminal area at the site of the thrombosis is relatively hypodense (delta sign) $(3,5,8,11)$. MR imaging and MR venography are the most sensitive techniques in determining CVST. In this technique, there is no sign of flow in the occluded vein or sinus and the parenchymal changes can also be evaluated $(5,8,11,14)$. We detected hemorrhagic areas at the left parietal lobe in the MRI examination of our case and did not detect any sinovenous and ipsilateral extracranial internal jugular venous blood flow in several intracranial segments in the MR venography examination.
Anticoagulant agents are used in the treatment of CVST (7). Our patient was discharged from the hospital with oral anticoagulant treatment, following the 2-week intravenous anticoagulant treatment.

\section{CONCLUSION}

In this report, we present a case of nephrotic syndrome with ipsilateral internal jugular venous thrombosis, accompanied by sinovenous thrombosis that involved several segments in the cranial region. To the best of our knowledge, this is the first case ever reported in the literature with this type.

\section{REFERENCES}

1. Akatsu H, Vaysburd M, Fervenza F, Peterson J, Jacobs M: Cerebral venous thrombosis in nephrotic syndrome. Clin Nephrol 48(5):317-320, 1997

2. Barthélémy $M$, Bousser $M G$, Jacobs $C$ : Cerebral venous thrombosis, complication of the nephrotic syndrome (author's transl). Nouv Presse Med 9(6):367-369, 1980

3. Burns A, Wilson E, Harber M, Brunton C, Sweny P: Cerebral venous sinus thrombosis in minimal change nephrotic syndrome. Nephrol Dial Transplant 10(1):30-34, 1995

4. Cameron JS: The nephrotic syndrome and it complications. Am J Kidney Dis 10:151-171, 1987

5. Ganeshan D, Narlawar R, McCann C, Jones HL, Curtis J: Cerebral venous thrombosis-a pictorial review. Eur J Radiol 74:110-116 2010

6. Hirata M, Kuroda M, Koni I: Cerebral venous thrombosis in minimal change nephrotic syndrome. Nihon Jinzo Gakkai Shi 41(4):464-468, 1999

7. Komaba H, Kadoguchi H, Igaki N, Goto T: Early detection and successful treatment of cerebral venous thrombosis associated with minimal change nephrotic syndrome. Clin Nephrol 68(3):179-181, 2007

8. Lin A, Foroozan R, Danesh-Meyer HV, Franzco De Salvo, Savino PJ, Sergott RCG: Occurrence of cerebral venous sinus thrombosis in patients with presumed idiopathic intracranial hypertension. Ophthalmology 113:2281-2284, 2006

9. Llach F: Hypercoagulability, renal vein thrombosis and other thrombotic complications of nephrotic syndrome. Kidney Int 28:429-439, 1985

10. Mandai K, Tamaki N, Kurata H, Fukada Y, lijima I, Nakamura H: A case of intracranial hemorrhage following superior sagittal sinus thrombosis associated with nephrotic syndrome. No Shinkei Geka 25(12):1101-1103, 1997

11. Muthukumar N: Cerebral venous sinus thrombosis and thrombophilia presenting as pseudo-tumour syndrome following mild head injury. J Clin Neurosci 11(8):924-927, 2004

12. Nishi $H$, Abe A, Kita A, Toki T, Noda N, Tsuchihashi D, Abe T, Umezu M, Yokozaki H, Fukagawa M: Cerebral venous thrombosis in adult nephrotic syndrome due to systemic amyloidosis. Clin Nephrol 65(1):61-64, 2006 
13. Oktar N, Dalbasti T: Protein S deficiency, epileptic seizures, sagittal sinus thrombosis and hemorrhagic infarction after ingestion of dimenhydrinate. Turk Neurosurg 18(1):85-88, 2008

14. Ozkurt S, Temiz G, Saylisoy S, Soydan M: Cerebral sinovenous thrombosis associated with factor $\mathrm{V}$ Leiden and methylenetetrahydrofolate reductase $\mathrm{A} 1298 \mathrm{C}$ mutation in adult membranous glomerulonephritis. Ren Fail 33(5):524-527, 2011
15. Sung SF, Jeng JS, Yip PK, Huang KM: Cerebral venous thrombosis in patients with nephrotic syndrome--case reports. Angiology 50(5):427-432, 1999

16. Xu H, Chen K, Lin D, Dai L, Chen H, Xu Z: Cerebral venous sinus thrombosis in adult nephrotic syndrome. Clin Nephrol 74(2):144-149, 2010 